\title{
GERMAN CHRISTIAN CONTRIBUTIONS TO JEWISH LAW*
}

\author{
Haim H. Cohn**
}

I have chosen for my subject some of the contributions made to Jewish law - in its widest sense - by German Christian scholars of the 16 th, 17 th and 18 th centuries. Some sixty years or more ago I became acquainted with the writings of John Selden, the 17th century English lawyer, parliamentarian and antiquarian, whose books on the Uxor Hebraica and De successionibus ad legem Ebraeorum, and De synedriis, were a revelation to me: for a non-Jewish scholar of that period to be capable of delving into biblical, talmudical and posttalmudical sources and to compare them with other ancient systems of law, was an unexpected feat. It is not only the impeccable command of Hebrew and Aramaic that excites wonder: it is also a sincere and genuine endeavour to comprehend and describe the workings of Jewish law objectively and without religious bias. We shall see that not all theologians always succeeded in suppressing their innate prejudices; there were even a good many who conducted their Judaistic research for hostile purposes (and with those I shall not deal). Even of Selden it was said that he had voiced now and then some antisemitic remarks, but there is no trace of any personal animus in his books on Jewish law.

There is some evidence to support the assumption that Selden had contact with, and was encouraged by, Johannes Buxtorf, Professor of Hebrew at the University of Basel. If only for that reason, I start my presentation with a short account of the Buxtorf dynasty - father, son

* This paper was presented at an International Colloquium held in Jerusalem in March, 1998.

I wish to acknowledge the debt I owe Professor Nahum Rakover whose Multilingual Bibliography of Jewish Law (Jerusalem, 1990) was of great assistance to me in preparing this paper. The fact that I have had to rectify some errors that crept into his book does not derogate from its usefulness. I further wish to express my gratitude to Dr. Christian Wiese, of the Steinheim Institute for German-Jewish History in Duisburg, for having supplied me with some biographical data which were not available to me here.

** Former Deputy President, Supreme Court of Israel. 
and grandson - who excelled as Hebraists. They all lived and taught in Basel, but originated from Westphalian stock. Johannes Buxtorf senior was born there in 1564 and died in Basel in 1629. His magnum opus was the Concordantiae Bibliorum Hebraicae, a monumental folio volume listing every word and phrase occurring in the Bible with Latin translation and explanation, to the second edition of which his son added a long Praefatio as well as a Concordantia Chaldiis. This work was not only epochal in the Christian world, but had as yet neither precedent nor companion in Jewish literature. To the best of my knowledge, Buxtorf was the first precursor of Mandelkern and the other Jewish concordancers. It is noteworthy that at the conclusion Buxtorf wrote, תם ונשלם שבח לאל בורה עולם an eminently rabbinical tailpiece to which some equilibrium was restored by his son who added Soli Deo Gloria. Not in vain was the father known in academic circles as Rabbinorum Magister. A second major book of his, De abbreviaturis hebraicis cum bibliotheca rabbinica et recensione operum talmudicorum, is the first and most comprehensive dictionary of abbreviations used in the Talmud. In explaining them the author touched very often and very elaborately on talmudico-legal conceptions. That this book (of more than 500 pages) supplied a very real need, probably not only among theologians, is indicated by the fact that between 1613 and 1708 it went into five editions. I shall mention two other books of Buxtorf the father (not listed by Rakover). One is entitled Epistolas hebraicas e institutionem epistolarum rabbinicum hebraicum: it describes and criticises the rabbinical system of adjudicating and legislating by correspondence - a system which, though not entirely unknown in Christian and Muslim medieval practices, had been cultivated to perfection by the rabbis. This book appeared in 1610: five years earlier he had published a pamphlet in German by the name of Juden Schul, which was later translated into Latin under the title Synagoga Judaica. This was his only publication averse to the Jews of his time: he disdained their self-seclusion in their synagogues and learning houses and their arrogant superciliousness towards the Christian faith. After his death, his son published a catalogue of the Hebrew books he had left: they numbered more than 300 - which at that time must have been well nigh complete.

His son wrote his doctoral dissertation (erroneously attributed to the father by Rakover) De sponsalibus et divortiis cui accessit Isaaci Abarbanelis diatriba - the biblical law on marriage and divorce, in which he joined Isaac Abravanel's "diatriba" against traditional interpretations (1652). He was not the first Christian scholar who was 
acquainted with Abravanel's writings: Grotius quotes him copiously, and Calvin attacks him sharply. But the younger Buxtorf himself had translated parts of Abravanel's commentaries into Latin, and though he differed from him occasionally, is reported to have been one of his staunchest admirers (B. Netanyahu, Don Isaac Abravanel — Statesman and Philosopher (1982) $325 \mathrm{n}$. 204). He also translated into Latin the Maimonidean מורה נבוכים (Doctorem Perplexorum) and the Kusari of Yehuda Halevi. Among his writings on biblical themes (not listed by Rakover) are discourses on אש תמיד (igne sacro), urim et tumim, manna, נחש הנחושת (de serpente aeneo), as well as polemics in defence of Judaism against oblique Christian scholars, and a comprehensive anthology of Hebrew phrases (Florilegium hebraicum sententiae). Like his father, he was a hebraist, not a lawyer, but their influence on Christian research into biblical and rabbinical law cannot be overestimated. A third generation Buxtorf, again professor of Hebrew in Basel, wrote a book which he called in Hebrew ספר הקבוצים or, in Latin, Catalecta philologicatheologica hebraica - another anthology of poetic biblical passages, interpreted from both the philological and the theological angles.

Anachronistically, I started with the 17th century (to which I shall in due course return) - as if the 16th had nothing to offer. I shall content myself with a short survey of 16 th century German scholars who excelled in Jewish learning and made their contribution to Jewish legal research. It was the century of the Reformation, and the Lutheran emphasis on the Old and New Testaments as the source of religious truth prompted an interest in biblical studies and brought forth, side by side with the interest in the Hebrew Bible and its Hebrew commentators, an entire school of enthusiastic Hebraists. This explains why most of the Christian Hebraists were Lutheran. Jesuits or other Catholics were rare exceptions.

Having said this, I shall pay tribute first to the exceptional Jesuit. Nicolaus Serarius (1555-1609) was famous for his extraordinary fluency in ancient languages. He taught theology and canon law at the universities of Wurzburg and Mainz. He wrote elaborate commentaries on the books of the Bible following the Pentateuch, and the apocrypha of Tobias, Judith and the Maccabees - perhaps he excelled in biblical research to show the Lutherans that what they could do, he could do better. His book Pharisees, Sadducees and Essenes (the only one listed by Rakover) is not only a historical account, but an attempt - from the orthodox Christian point of view - to restate their respective religious, legal and political doctrines. 
Two of his contemporaries, Eduardo Hilderius and Marcus Antonius Probus, one professor in Wittenberg and the other in Eisleben, both Lutheran strongholds, engaged independently of each other in research into biblical public law. Hilderius wrote on Politia et hierarchia populi Judaici (1570), and Probus on De monarchia regni Israelis (1585). Both give a lucid account of the legal and political build-up of the theocratic monarchy. While Hilderius concluded his career with a professorship of Hebrew at Heidelberg, nothing is known of any proficiency in Hebrew by Probus.

This brings me back to the 17th century. We have seen that the elder Buxtorf left his native Germany and settled in Switzerland where his sons and grandsons were born. It may be of interest to note that several other German hebraists likewise pursued their academic careers at Swiss universities. Whether the demands for Hebrew teaching and research were greater or more encouraged there than in Germany, or whether it was the free and democratic Switzerland that attracted them, I cannot say: those who went to Geneva were, of course, Calvinists; but of those who went to Basel or Zurich only a few adopted the Swiss reformed religion.

One of the most eminent professors of Hebrew and other oriental languages in Zurich was Johannes Nericus Hottinger (1620-1667). He was a Swiss Reformist and is reported to have hired a learned Jew to teach him Hebrew and Talmud, and after several obviously fruitful years of study with him he hired a learned Muslim to teach him Arabic and Islamics. Though he died young - he was drowned ("ersoffen") in a shipwreck - he left an enormous amount of writings, ranging from theology to philology, history, archaeology, and canon and Jewish law. In 1655 he published his Iuris Hebraeorum leges, a compendium in collaboration with some other scholars. The laws of the Bible (mitzvot) are there enumerated and explained in concise language. In the subtitle to his book, Hottinger acknowledges that he had been guided by the writings of Rabbi Levi Barselonita - whom Rakover erroneously identifies as Rabbi Aharon Halevi הרא"ה. It is manifest that Hottinger's book is patterned after ספר החינוך which was widely disseminated and had been translated into Latin, French and Spanish. Its author presented himself as Levi of Barcelona, and it was for a long time generally assumed that he was indeed identical with $R$. Aharon Halevi. This assumption has been conclusively disproved, and Hottinger's is the authentic Levi of Barcelona who signed as author of ספר החינוך and of whom we know nothing else. Some years later he published a Compen- 
dium theologiae Judaicae (not listed by Rakover), containing elaborate commentaries on the 13 Maimonidean articles of faith. To this theological compendium he added his Epitomen juris Juclaici, a concise statement of biblical law. Finally, his Analecta historico-theologiae also contain comparative research into the law of שמיטה ויובל, as well as a comparative survey of Jewish and Muslim religious practices.

Another eminent Hebraist was Johann Christoph Wagenseil (16331705) - but he differs from all the others in that he was professor not only of oriental languages but also of law. He had widely travelled all over Europe and had earned his doctorate juris in Orleans, France. He specialized in canon law and Jewish law, and translated the Talmud into Latin. Of this translation, only the tractate of Sotah has been preserved to us. It was published in 1674 in a folio volume comprising 1363 pages - for it contains not only translations of Mishna and Gemara, but also of all the relevant passages of the עין 'עקב, an agadic compendium of R. Yaakov Ibn Habib of Salonica (1445-1506), and Wagenseil's awn commentaries. He wrote discourses on the Maimonidean לא יסור 49:10 לaws of oath and on the year of jubilee, as well as on Gen. שבט מיהודה. His researches into Hebraistics and Jewish law went side by side with his enmity against the Jews who lived in Germany. He published a "Sammlung von Schriften, welche die Juden betreffen", and had it distributed to all regents and rulers who had Jews under their dominion, calling upon them not to suffer Jewish slanders of Jesus Christ, and setting out in detail such rights and privileges as Jews may legitimately be accorded. Perhaps the most gratifying thing that can be said of Wagenseil is that he had a daughter, Helena Sybilla Mollern, who was an accomplished Hebraist in her own right and made a new translation of the Psalms into German verses - probably the first Christian lady to master the Hebrew language.

As distinguished from Wasengeil, his younger contemporary Johann Franz Budde, better known as Buddeus (1669-1729) earned a reputation of what we nowadays call an ecumenist. Not that, loyal and orthodox Lutheran as he was, he would make any concession to Papists: but in his "Einleitung zu den vornehmsten Religions-Streitigkeiten" he gave a fair account not only of Catholic but also of Jewish and Muslim doctrine. He went even further and wrote a large, though less benignant, treatise on Theses de atheismo et superstitione. His main contribution to Jewish legal studies was his Synopsis iuris nature et gentium iuxta disciplina Hebraeorum, which went into four editions, and in which he showed in great detail that both natural and international law 
had their roots in biblical concepts. This must have been one of the first books to introduce Grotian theories to German scholarship. Another legal treatise ascribed to him and entitled Prudentia civilis rabbinicae specimen, apparently dealing with some aspects of talmudic law, I could not lay my hand on. He held professorships not only in theology but also in philosophy and in jurisprudence. His contribution to Jewish philosophy was an Introductio ad historiam philosophiae Hebraeorum, which also went into several editions, and in which he divulged an astounding familiarity with the great Jewish medieval philosophers. The dissertation by which he - rather late in life - earned his (third) doctorate in jurisprudence dealt with the innovations made by King Solomon, by his forensic practices as well as in his writings (mainly the Proverbs), to general Mosaic law.

The last - but by no means the least - 17th century scholar I should like to present to you is Augustus Pfeiffer (1640-1698). He is reported to have been proficient in all the proverbial seventy languages: however that may be, what we can readily attest to is his proficiency in Hebrew and Aramaic. His library is said to have contained hundreds of invaluable ancient manuscripts in Hebrew, Arabic, Persian and Chinese as well as in the European languages; and he also had a large collection of Jewish ritualia. He caught my imagination by the fact that at the height of his academic career, at the age of 50, he gave up his professorship of theology and philosophy at Leipzig, that great stronghold of learning, and commuted it for the small but beautiful and liberal city of Lübeck where he had been invited to serve as superintendent of the Lutheran churches. The scandalmongers of the day had it that his professorial colleagues could not stand him and his undisguised superiority complexes and had made life there unbearable to him. He must have been an inspired and inspiring preacher; his Orationes were published after his death in eleven volumes - one of them containing a series of 39 sermons on the subject of nuptialia, with very vivid and highly imaginative accounts of all biblical marriages, the marriage of Isaac and Rebecca being, curiously enough, singled out as particularly worthy of imitation ("Eheschule"). All his contributions to Jewish law were marked by an emphasis on mores, in the sense of ethical theory as well as a ritual and domestic practice. He compiled a collection of some of his papers on the subject as Antiquitates Ebraicae selectae. Of special significance there is his discourse de moribus scholasticis Ebraeorum, giving a very detailed and well informed account of הלכות תלמוד תורה, their interpretation by later rabbis and their practical implementation: 
he held this out as a pattern for enlightened scholastic education. His early dissertation De Talmude Judaeorum was followed by several articles on talmudical structures and conceptions: they were apparently intended to form a nucleus to a comprehensive introduction. He also wrote a Philosophia Mosaica, and two grammatical treatises: De Accentibus Hebraicis, on the purposes and functions of the various Degashim; and a general Thesaurum grammarices hebraeorum. Mention should be made, in conclusion, of his translation into Latin, with an elaborate commentary of his own, of Abravanel's Commentarium in prophetas priores - again apparently the beginning of a larger undertaking which had to be discontinued.

In addition to their own enormous prolificity - their Judaistic work was only a small part of their total output - most of these scholars had to direct and supervise doctoral candidates and their dissertations. Many of these dissertations have been preserved to us - not under the names of their authors, but under the names of the professors who presided over the examinations. Rakover lists about twenty such dissertations on Jewish law subjects, but there must have been many more. Their titles and tenors show a variety of approaches and interests, from more general to more particular subject matters. Very popular are the themes connected with the New Testament: for instance, on the composition and function of the Sanhedrin, or on the Trihaeresio - the triple heresies - of Pharisees, Sadducees and Essenes; a good many deal with problems of conversion and proselytization; there are a few about the jubilee year, about cities of refuge, about marriage and divorce, on the laws of war, and on Shabbat healings for פיקוח נפש. I found one on the legal relevancy of בת קול, voices from heaven; and in the last decade of the century, there were in Strassburg at least five dissertations about the laws against magic and magicians - apparently the predisposed or preeminent concern of the presiding professor, a man by the name of Zentgraff. That these dissertations, and a great number of other judaistic writings of that age, have been preserved to us, we owe to the life-long effort of an Italian Jesuit of Jewish descent, Blasius Ugolinus (17001770); he made it his business to bring into Christendom not only his own soul and body, but also both the primary sources of Judaism and their secondary expositions. Nineteen of the 34 folio volumes of his Thesaurus Ugolinus contain his own translations into Latin of the Sedarim of Zera'im and Nashim in full and the tractates of Sanhedrin, Arachin and Bechorot - the full texts of Gemara and Tossefta, and for Zera'im and Moed also the Yerushalmi, the "Gemara Hierosolymitana". 
The remaining volumes contain works of other authors, all on the subject of the mores, leges, institutia, ritus sacri et civilis veterum Hebraeorum.

As distinguished from other Jewish apostates who spared no effort to revile and calumniate Jews and Judaism in the eyes and ears of Christendom, our Frater Ugolinus exercised scholarly objectivity and excelled as a precisionist - perhaps in order to show how great a sacrifice it was to leave such lofty Judaism even for the sake of Christianity.

The 18th century heralded more religious liberty and academic freedom - which resulted also in an ever growing interest in ancient and comparative law. Among the dissertations I found one dated as early as 1687 and devoted to the postulate of libero religionis exercitio, the free exercise of religion. The wide field of Judaistic research which had in the main been the realm of theologians, slowly captured the interest also of jurists: a Hallenser law professor by the name of Thiel published a big volume entitled Principia jurisprudentiae judaicae; and a renowned Tübinger criminalist by the name of Gmelin published a very accurate and still useful account of the Rechte der Juden in Peinlichen Sachen. This followed a Swiss prize winning contest for the best and most complete project of effective criminal legislation. And Gmelin was not the only one who thought that many facets of Jewish criminal law were worthy of consideration and adaptation even in a modern criminal code. About two decades before Gmelin's book, there appeared Johann David Michaelis's voluminous work on Mosaic law — and to the man and his work I shall devote the rest of this paper.

Michaelis (1717-1791) officiated as a pastor in his native Göttingen. He had academic ambition and literary talent, and decided to devote himself to the study of Hebrew. He graduated with a dissertation de punctorum Hebraicorum antiquitate, an exposition of the origins and workings of the ניקוד which was followed first by a book on the Anfangsgründe der hebräischen Akzentation, and later by a comprehensive Hebräische Grammatik which went into several editions. Having accomplished that, he seems to have taken some respite from Hebrew and immersed himself in belles-lettres, translating English novels and plays into German. Then appeared his Programma von der Verpflichung der Menschen die Wahrheit zu reden: he proved a punctilious grammarian, belletricist and moralist in one. Somehow or other he started to divert his interest to the legal aspects of the Hebrew antiquities: his treatise on the Ehegesetze Mosis, with special reference to marriage 
impediments, was the forerunner of several other monographs, of which the one on the prohibition of usury was the most elaborate - it surveyed all known usury laws of the ancient world to prove the superiority of the Mosaic law. When his expertise in ancient Jewish law had become a matter of common knowledge, he was one day approached by a famous Privy Councillor of Sweden, called Olaus Rabenius, to whom his sovereign had assigned the task of drafting new constitutional and criminal codes for Sweden. He solicited advice from Michaelis as to the potential usefulness and relevancy of Mosaic law to modern legislation; and he told him that Mosaic law still subsisted in Sweden as a residuary law, although nobody there was really familiar with it. Michaelis writes that he saw this as a great challenge - and the result was his magnum opus, the six-volume treatise on Mosaisches Recht.

He himself emphasizes that Mosaic law is not identifiable with Jewish law: in order to study the law which the Jews of his day considered binding upon them, you had to delve into the Talmud which was not what our author contemplated. For him, Jesus teaching that the Pharisees had corrupted the laws of Moses, was the ultimate truth; though he adds that Talmudic law was in and of itself worthy of study, not as a moral or logical continuation or perpetuation of Mosaic law, but rather as a legal system on its own merits. Talmudic law may, for the period following the destruction of the Second Temple, well have provided the best - or a reasonably good - legal order for the needs of that particular generation - as, indeed, Mosaic law had provided the very best imaginable legal order for the people of Israel in biblical times. He stresses the fact that each and every people need laws of their own, adapted not only to their customary traditions, but also to the conditions and circumstances of their lives and livelihoods, to the nature of their lands and their resources, as well as their moral and religious orientation. And this is the reason why Mosaic law, however ideal a system it was for the ancient Israelites, ought not to be transplanted in toto to any other people in any other land at any other period of time: it is only certain particular legal institutions which may conceivably be adopted, in some form or another, also by later legislators elsewhere. And this is also the reason why Mosaic law is no longer binding even on the Jews: quite apart from the explicit Pauline dispensation, laws which were good for one - however extended - period of time, are not necessarily good for any other period, and the circumstances of life have changed, and are continuously changing, in a way that those ancient laws can no longer respond to the needs of the people. That his Swedish codificator 
was not too disappointed, is evident from the laudatio he wrote him (and which Michaelis printed at the head of the second edition).

Moses was, of course, the greatest and most ingenious lawgiver the world had ever seen. Not only his personal genius, but also his practical Egyptian and Midjanie experiences, and his thorough and intimate knowledge of the idiosyncracies and predilections and, in particular, obstinacies of his own people, made for his selection by God as the greatest leader of Israel. Michaelis does not question the divine origin of Mosaic law, but he seems to ascribe to Moses some kind of legislative discretion, which of God's laws to enact and which to leave in the folds of heaven; and he also seems to be invested with power to enact divine laws which God Almighty would perhaps not have seen fit for human consumption. God, being the king of all kings, could, of course, if he so desired, have chosen also leaders of other peoples to entrust them with his laws. That he did not do so, is not only proof of the chosenness of Israel but also of the outstanding and unique eminence of Moses. But this particular choice goes also to prove that God did not intend his laws to be observed by other peoples - if only, because they each had their own gods who were so inferior to him as to render their acceptability inconceivable. And while Moses had been empowered to impose the divine laws on the people of Israel, eventually Jesus and the Apostles were divinely charged with the task of discontinuing the binding force of the divine Mosaic law; or, in some instances, to reinstate the divine law which Moses had seen fit to abrogate, as e.g., the indissolubility of marriages.

The historian of German criminal justice, Eberhard Schmidt, acknowledges the contribution of Michaelis to German penal reform, mainly on the ground that he did away with religious prejudices still rampant to the effect that good Christians should be expected to restore the divine law to life. He calls him a "rationalist", to wit, there is a theologian reasonable enough to venerate and glorify divine law and at the same time to propound its obsolescence.

As far as his contribution to a better understanding of Mosaic law is concerned, I dare say that modern Bible research has long eclipsed his well-meant assiduities and novel insights. But then that can be said of all those contributions to Jewish law and Jewish studies of which I have spoken: our interest in them lies not so much in their practical results, if any, as in their scholarly motivation. 